\title{
Article
}

\section{Finger whitlows}

\author{
Nuttall, Dilyse
}

Available at http://clok.uclan.ac.uk/23358/

Nuttall, Dilyse ORCID: 0000-0002-0561-5229 (2018) Finger whitlows. Nurse Prescribing, 16 (6). pp. 260-261. ISSN 2052-2924

It is advisable to refer to the publisher's version if you intend to cite from the work.

10.12968/npre.2018.16.6.260

For more information about UCLan's research in this area go to

http://www.uclan.ac.uk/researchgroups/ and search for <name of research Group>.

For information about Research generally at UCLan please go to http://www.uclan.ac.uk/research/

All outputs in CLoK are protected by Intellectual Property Rights law, including Copyright law. Copyright, IPR and Moral Rights for the works on this site are retained by the individual authors and/or other copyright owners. Terms and conditions for use of this material are defined in the policies page.

\section{CLoK}

Central Lancashire online Knowledge www.clok.uclan.ac.uk

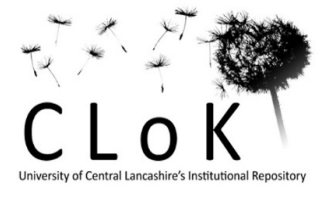




\section{Calculation Skills: Whitlow}

A whitlow, also known as a felon, is a closed space infection of the distal finger pulp (Franko and Abrams, 2013), commonly presenting as redness, tenderness and swelling (NICE, 2016). McDonald et al (2011) state that the most common cause of infection to the hand area is staphylococcus aureus, and causes up to $80 \%$ of staphylococcal whitlows (NICE, 2016). Whitlows can also be caused by the herpes virus and are known as herpetic whitlows, with symptoms often also including blistering (NHS, 2017).

No UK data is available but data from America suggests that staphylococcal whitlow (including paronychia), accounts for a third of hand infections, whilst the prevalence of herpetic whitlow is 2.4 per 100,000 annually (NICE, 2017).

\section{Question 1}

Referring to table 1 and assuming that the American figures reflect the UK prevalence of herpetic whitlow, answer the following questions:

(i) How many cases of staphylococcal whitlow would you expect to have seen in town E in 2017?

(ii) What would you expect the combined annual prevalence of herpetic whitlow to be in towns $A, B$ and $C$ to be? Round your answer up or down to the nearest whole number.

(iii) In which town did $0.12 \%$ (rounded to two decimal points) of its population have a hand infection in 2017?

\begin{tabular}{|l|l|l|}
\hline \multicolumn{3}{|l|}{ Table 1: Incidence of hand infection } \\
\hline UK Town & Population & $\mathbf{2 0 1 7}$ cases of hand infection \\
\hline A & 20,700 & 6 \\
\hline B & 6,700 & 3 \\
\hline C & 61,600 & 24 \\
\hline D & 37,700 & 18 \\
\hline E & 12,400 & 15 \\
\hline
\end{tabular}


Question 2

NICE (2016) recommend the treatment regime identified in table 2, for staphylococcal whitlow.

(i) Rupert, aged 21 years, has a staphylococcal whitlow and is prescribed flucloxacillin. He is prescribed the highest recommended dose. Both $250 \mathrm{mg}$ and 500mg capsules are available. Prescribing the fewest number of capsules, how many will need to be prescribed to complete the 7 day course?

(ii) Sally is 4 years old and weighs $16 \mathrm{~kg}$. She is prescribed clarithromycin. What daily dose will Sally require?

(iii) Abigail is a 30 year old breastfeeding mother who is allergic to penicillin. She is prescribed the lowest recommended dose of erythromycin for a whitlow. How much erythromycin (in grams) will she have taken on completion of the 10 day course?

(iv) Tom is a $7 \mathrm{~kg}$ infant, what is the daily dose of clarithromycin that he would need?

\begin{tabular}{|c|c|c|c|}
\hline & Drug & Age & Dose \\
\hline \multirow[t]{3}{*}{ First Line } & \multirow[t]{3}{*}{ Flucloxacillin } & $\begin{array}{l}\text { Adults \& children over } \\
10 \text { years }\end{array}$ & $\begin{array}{l}250 \mathrm{mg} \text { to } 500 \mathrm{mg} \text {, four } \\
\text { times a day }\end{array}$ \\
\hline & & Children $2-10$ years & $\begin{array}{l}125 \mathrm{mg} \text { to } 250 \mathrm{mg} \text {, } \\
\text { four times a day }\end{array}$ \\
\hline & & $\begin{array}{l}\text { Children } 1 \text { month to } 2 \\
\text { years }\end{array}$ & $\begin{array}{l}62.5 \mathrm{mg} \text { to } 125 \mathrm{mg} \text {, } \\
\text { four times a day }\end{array}$ \\
\hline \multirow{7}{*}{$\begin{array}{l}\text { Alternative if } \\
\text { allergic to } \\
\text { penicillin }\end{array}$} & \multirow[t]{7}{*}{ Clarithromycin } & $\begin{array}{l}\text { Adults and children } \\
\text { older than } 12 \text { years }\end{array}$ & $\begin{array}{l}250 \mathrm{mg} \text { to } 500 \mathrm{mg} \text {, } \\
\text { twice daily }\end{array}$ \\
\hline & & $\begin{array}{l}\text { Children } 1 \text { month to } 12 \\
\text { years according to } \\
\text { body weight: }\end{array}$ & \\
\hline & & less than $8 \mathrm{~kg}$ & $\begin{array}{l}7.5 \mathrm{mg} \text { per kg twice } \\
\text { daily }\end{array}$ \\
\hline & & $8-11 \mathrm{~kg}$ & $62.5 \mathrm{mg}$ twice daily \\
\hline & & $12-19 \mathrm{~kg}$ & 125 mg twice daily \\
\hline & & $20-29 \mathrm{~kg}$ & $187.5 \mathrm{mg}$ twice daily \\
\hline & & $30-40 \mathrm{~kg}$ & $250 \mathrm{mg}$ twice daily \\
\hline \multirow{3}{*}{$\begin{array}{l}\text { Alternative if } \\
\text { allergic to } \\
\text { penicillin / } \\
\text { and if } \\
\text { breastfeeding }\end{array}$} & \multirow[t]{3}{*}{ Erythromycin } & $\begin{array}{l}\text { Adults and children } \\
\text { older than } 8 \text { years }\end{array}$ & $\begin{array}{l}250 \mathrm{mg} \text { to } 500 \mathrm{mg} \text {, } \\
\text { four times a day }\end{array}$ \\
\hline & & Children $2-8$ years & $\begin{array}{l}250 \mathrm{mg} \text {, four times a } \\
\text { day }\end{array}$ \\
\hline & & $\begin{array}{l}\text { Children } 1 \text { month to } 2 \\
\text { years }\end{array}$ & $\begin{array}{l}125 \mathrm{mg} \text {, four times a } \\
\text { day }\end{array}$ \\
\hline
\end{tabular}

\section{Question 3}

Stan has a recurring herpetic whitlow and is to be treated with acyclovir as it is less than 48hours since the whitlow developed. The recommended dose is $200 \mathrm{mg}$, five times daily, for five days but because he is immunosuppressed, the dose is to be doubled. Due to swallowing difficulties, he is prescribed oral suspension $200 \mathrm{mg} / 5 \mathrm{ml}$. 
(i) What amount of oral suspension is needed for a daily dose?

(ii) How much oral suspension will need to be prescribed to enable the duration of the course to be extended by $40 \%$ ?

Question 4

Public Health England (2015) wants to reduce antimicrobial resistance, with a reduction in the prescribing of antibiotics identified as one of the key strategies. They reported a $6.5 \%$ increase in antibiotic consumption over a 4 year period, expressed as a defined daily dose (DDD) per 1000 of the population.

(i) Assuming the increase was consistent over the 4 year period, what percentage would the increase have been over the first 6 months? (rounded up or down to one decimal point).

(ii) The defined daily dose (DDD) of antibiotics per 1000 people was 21.6 in 2011 . What was the DDD in 2015? (rounded up or down to the nearest whole number)

(iii) Assuming a 5\% drop in antibiotic consumption from the 2015 DDD by 2020, what will the 2020 DDD be?

\section{Answers}

Question 1

(i) $15 \div 3=5$

(ii) Prevalence rate $=2.4 / 100,000$ or $0.0024 / 100=0.0024 \%$

Combined population $=89,000$

$89,000 \div 100 \times 0.0024=2.136$

annual prevalence $=2$ (rounded down)

(iii) Town $A=6 \div 20,700 \times 100=0.03$

Town $B=3 \div 6,700 \times 100=0.05$

Town $C=24 \div 61,600 \times 100=0.04$

Town $D=18 \div 37,700 \times 100=0.05$

Town E $=15 \div 12400 \times 100=0.12$

Answer is town $\mathrm{E}$

Question 2

(i) Course $=(500 \mathrm{mg} \times 4) \times 7=14000 \mathrm{mg}$

$14000 \div 500=28$ capsules

(ii) $125 \mathrm{mg} \times 2=250 \mathrm{mg}$

(iii) Course $=(250 \mathrm{mg} \times 4) \times 10=10000 \mathrm{mg} / 10 \mathrm{~g}$ 
(iv) $\quad(7.5 \times 7) \times 2=105 \mathrm{mg}$

\section{Question 3}

Stan has a recurring herpetic whitlow and is to be treated with acyclovir as it is less than 48hours since the whitlow developed. The recommended dose is $200 \mathrm{mg}$, five times daily, for five days but because he is immunosuppressed, the dose is to be doubled. Due to swallowing difficulties, he is prescribed oral suspension $200 \mathrm{mg} / 5 \mathrm{ml}$.

(i) Daily dose $=400 \mathrm{mg} \times 5=2000 \mathrm{mg}$

$2000 \quad 00 \times 5=50 \mathrm{mls}$

(ii) Normal course $=5$ days

$$
40 \%=\frac{5}{100} \times 40=2 \text { days }
$$

Extended course $=2+5=7$ days

$50 \mathrm{ml} \times 7=350 \mathrm{ml}$

Question 4

Public Health England (2015) wants to reduce antimicrobial resistance, with a reduction in the prescribing of antibiotics identified as one of the key strategies. They reported a $6.5 \%$ increase in antibiotic consumption over a 4 year period.

(i) $6.5 \%$ over 4 years $=0.8 \%$ over 6 months (rounded down)

(ii) $\quad(21.6 \div 100) \times 6.5=1.404 \quad 21.6+1.404=23.04 \quad 23$ (rounded down)

(iii) $\quad 2015=23 \quad 5 \%=(23 \div 100) \times 5=1.15 \quad 23-1.15=21.85$

References

Franko, O.I. and Abrams, R.A. (2013) Hand infections. Orthop Clin North Am. 44(4): 625-634

McDonald, L.S., Bavaro, M.F. and Hofmeister, E.P. et al (2011) Hand infections. Journal of Hand Surgery. 36(8): 1403-1412.

NHS Choices (2017). Herpetic whitlow (whitlow finger), NHS Choices, available at: https://www.nhs.uk/conditions/herpetic-whitlow/

NICE (2016) Whitlow (staphylococcal and herpetic), Clinical Knowledge Summaries, available at: https://cks.nice.org.uk/whitlow-staphylococcal-and-herpetic\#!topicsummary 
Public Health England (2015) Health Matters: Antimicrobial Resistance, available at:

https://www.gov.uk/government/publications/health-matters-antimicrobial-resistance/healthmatters-antimicrobial-resistance 